\title{
An imaging genetics approach to understanding social influence
}

\author{
Emily B. Falk ${ }^{1,2 *+}$, Baldwin M. Way ${ }^{3 *}$ and Agnes J. Jasinska ${ }^{2}$ \\ ${ }^{1}$ Department of Communication Studies and Institute for Social Research, University of Michigan, Ann Arbor, MI, USA \\ 2 Department of Psychology, University of Michigan, Ann Arbor, MI, USA \\ ${ }^{3}$ Department of Psychology and the Institute for Behavioral Medicine Research, The Ohio State University, Columbus, OH, USA
}

Edited by:

Chad E. Forbes, University of

Delaware, USA

Reviewed by:

Eveline A. Crone, Leiden University,

Netherlands

Carrie Masten, Vanderbilt University, USA

\section{${ }^{*}$ Correspondence:}

Emily B. Falk, Department of

Communication Studies and

Institute for Social Research,

University of Michigan,

426 Thompson St, Ann Arbor,

MI 48104, USA.

e-mail: ebfalk@umich.edu

Baldwin Way, Department of

Psychology, The Ohio State

University, 100G Lazenby Hall,

1827 Neil Avenue, Columbus,

$\mathrm{OH} 43201$, USA.

e-mail:way.37@osu.edu

†These authors contributed equally

to this work.
Normative social influences shape nearly every aspect of our lives, yet the biological processes mediating the impact of these social influences on behavior remain incompletely understood. In this Hypothesis, we outline a theoretical framework and an integrative research approach to the study of social influences on the brain and genetic moderators of such effects. First, we review neuroimaging evidence linking social influence and conformity to the brain's reward system. We next review neuroimaging evidence linking social punishment (exclusion) to brain systems involved in the experience of pain, as well as evidence linking exclusion to conformity. We suggest that genetic variants that increase sensitivity to social cues may predispose individuals to be more sensitive to either social rewards or punishments (or potentially both), which in turn increases conformity and susceptibility to normative social influences more broadly. To this end, we review evidence for genetic moderators of neurochemical responses in the brain, and suggest ways in which genes and pharmacology may modulate sensitivity to social influences. We conclude by proposing an integrative imaging genetics approach to the study of brain mediators and genetic modulators of a variety of social influences on human attitudes, beliefs, and actions.

Keywords: social influence, persuasion, fMRI, imaging genetics, reward, punishment, dopamine, serotonin
Folk wisdom suggests that "beauty is in the eye of the beholder," however, human judgments of people, objects, ideas, and experiences are strongly influenced by the reactions or valuations made by others. In fact, given the profound effects of social influence on human behavior, it may be more accurate to say, "Beauty is the consensus of many beholders." Forms of influence range from intentionally designed persuasive arguments (Petty and Cacioppo, 1986a,b; Chaiken et al., 1989; Eagly and Chaiken, $1993,2005,2007)$, to conformity in the face of peer influence (Casey et al., 2008b; Juvonen and Galván, 2008; Steinberg, 2008; Albert and Steinberg, 2011), to implicitly acquired local norms and cultural values (Cialdini and Goldstein, 2004; Goldstein et al., 2008). Such influences shape our attitudes, beliefs, and behaviors, both consciously and outside of conscious awareness (Cialdini and Goldstein, 2004). However, the power of normative social influences is subject to multiple contextual factors, and individuals are not uniformly susceptible across circumstances (Petty and Cacioppo, 1986a; Cialdini and Goldstein, 2004; Juvonen and Galván, 2008) or developmental periods (Casey et al., 2008b; Steinberg, 2008; Albert and Steinberg, 2011). Given that influence processes are moderated both by environmental and personlevel variables, interdisciplinary perspectives that combine social psychological, developmental, and biological theory may be especially fruitful in uncovering common pathways that underlie different types of influence, and factors that explain divergent results.

Consistent with this interdisciplinary perspective, a growing body of literature has identified neural mediators of the relationship between different forms of social influence and behavior. These data point toward several conclusions that provide the theoretical framework for this manuscript and which we briefly overview here, and summarize in Figure 1. First, as depicted in Figure 1, diverse forms of influence overlap in their underlying neural circuits. Therefore, we treat these diverse forms of influence together and use the umbrella term "normative social influences" to encompass a range of directly observed and inferred social and normative cues that motivate compliance, conformity, susceptibility to peer influence, and responsiveness to persuasion. Second, the constellation of brain areas identified in these studies comprises the brain's social reward and pain networks, which are likely mediators of social influence processes; in other words, as depicted in Figure 1, people may respond to normative social influences as a joint function of sensitivity to social rewards (conferred by conformity), as well as sensitivity to social punishment (conferred by violation of norms or rejection of persuasive inputs). Finally, as indicated in Figure 1, genetic variation affects the reactivity of these neural systems to social influences and thereby behavior. In addition, some genetic 


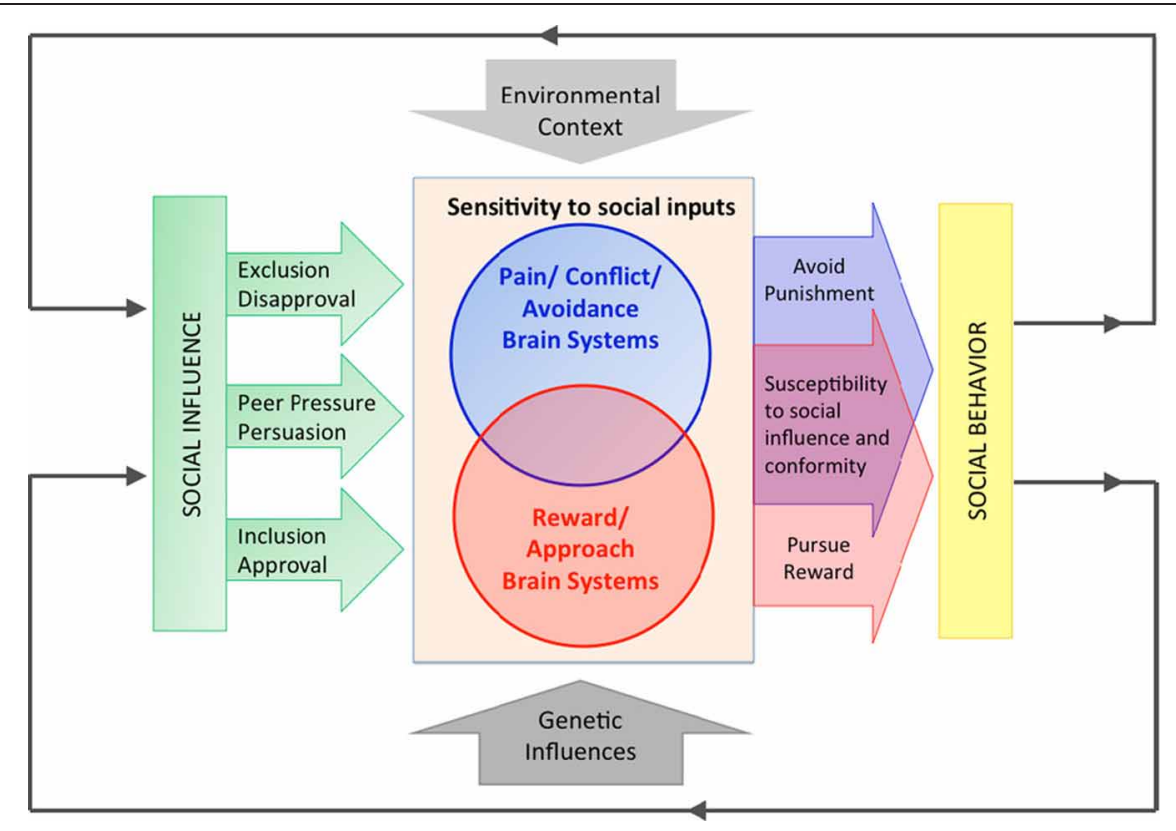

FIGURE 1 | An imaging genetics approach to understanding the neural mediators and genetic modulators of social influence. In this Hypothesis, we review evidence that neural systems sensitive to social rewards and social punishments mediate the relationship between social influences and behavior. We argue that these neural systems are moderated by genetic variants that confer increased sensitivity to social cues by increasing sensitivity in the brain's reward and punishment systems. Increasing evidence also suggests a neural and genetic overlap between reward and punishment processes in the brain, such that some genetic variants that increase sensitivity to social reward are also likely to increase sensitivity to social punishment. As depicted, these neural systems are also moderated by the broader social environment. Finally, although beyond the scope of this Hypothesis and omitted from the figure for simplicity, gene by environment interactions $(G \times E)$ are also likely to be critical in shaping the sensitivity to social influence. moderators affect the sensitivity of both systems through heightening responsiveness to both positive and negative social cues, such that genetic variants that increase sensitivity to social reward are also likely to increase sensitivity to social punishment. In this Hypothesis, we suggest a relational theory of social influence that bridges social psychological theories of influence (Cialdini and Goldstein, 2004) with extant neuroimaging and imaging genetics findings.

\section{SOCIAL REWARD/SOCIAL PUNISHMENT FRAMEWORK}

The same neural circuits that respond to primary rewards (e.g., food) and punishments (e.g., physical pain) also encode information about social rewards and punishments, likely due to the importance of preserving social bonds for human survival (Lieberman and Eisenberger, 2009; Takahashi et al., 2009). Approaching rewards and avoiding punishments are key motivational drivers across a number of domains (Skinner, 1963; Panksepp et al., 1978; Gray, 1990; Sobotka et al., 1992; Carver and White, 1994; Cacioppo et al., 1997). Reward tends to elicit approach and a positive emotional response, whereas punishment has the opposite effect of provoking withdrawal and a negative emotional response. This principle applies to rewards and punishments that are actually received as well as to those that are only anticipated (Adcock et al., 2006; Knutson et al., 2007; Knutson and Greer, 2008). Both reward and punishment also serve to trigger learning: in the case of reward, the specific behavior leading to the rewarding outcome is reinforced and likely to be repeated (Berridge, 2012), whereas in the case of punishment, the specific behavior leading to the aversive outcome is inhibited and thus prevented from reoccurring (Gray, 1987). Finally, a large body of research has documented individual differences in sensitivity to rewards and sensitivity to punishments in motivating behavior (Gray, 1990; Carver and White, 1994; Cacioppo et al., 1997), as well as in the neural correlates of approach and avoidance tendencies across stimulus valence (Harmon-Jones et al., 2006; Berkman and Lieberman, 2010).

Susceptibility to normative social influences may also be viewed in terms of social rewards and punishments that elicit and reinforce certain behaviors. Such behaviors are likely driven by the motivation to affiliate and maintain a positive self-concept, and correspondingly to avoid exclusion and triggers of negative self-concept (Cialdini and Goldstein, 2004). In this framework, we argue that one pathway of social influence would be the drive to pursue social rewards conferred by conforming (Albert and Steinberg, 2011). A second pathway of social influence would be avoidance of social punishment, including social exclusion (Williams et al., 2000). These processes might also extend to responses elicited by positive and negative persuasive messages or public service announcements (PSAs). We elaborate upon the inter-relationship between social conformity and reinforcement in the next section by discussing reward processing first and then punishment processing. 


\section{SOCIAL REWARD AND INFLUENCE: NEUROIMAGING EVIDENCE}

Conformity is one of the most basic and widespread forms of social influence (Sherif, 1936; Asch, 1955). Conforming to perceived social norms serves a number of adaptive purposes. Following the behavior of others can help us to be accurate, to connect with others, and to preserve a positive self-view (Cialdini and Goldstein, 2004). Consistent with the idea that conformity serves motivationally relevant goals, the neural regions that have been most frequently associated with conformity and responsiveness to social norms include the ventral striatum (VS) and ventromedial prefrontal cortex (VMPFC), key structures in detecting salient inputs, and also key components of the brain's reward system (Knutson et al., 2001; McClure et al., 2004b; Knutson and Cooper, 2005; Haber and Knutson, 2010). More dorsal aspects of the striatum and MPFC (Brodmann's Area 10; BA10) also track aspects of normative social influence, including popularity and social relevance, respectively (Mason et al., 2009).

As with other forms of attitudinal evaluation, it is likely that signals from the striatum and PFC are iteratively re-processed depending on contextual factors (Klucharev et al., 2008), internal motivation, and social cues to arrive at a final stimulus evaluation and goal-directed action (Cunningham and Zelazo, 2007; Cunningham et al., 2007). Numerous examples support the role of VMPFC in integrating such information. For example, in making choices about foods to consume, the VMPFC has been shown to integrate information about attributes such as healthiness and taste (Hare et al., 2009, 2011), as well as information reflecting societal value (Plassmann et al., 2008) and ultimately determines factors such as willingness to pay for such items (Plassmann et al., 2007). In fact, attributes that reflect societal value (e.g., price), have been shown to affect both the subjective experience of pleasantness during consumption, as well as neural activity in this circuit (Plassmann et al., 2008) cf. (McClure et al., 2004a). In addition, activity in VS and VMPFC increases in response to stimuli that have been rated positively by peers (Zaki et al., 2011), and when conforming to the opinion of others (Campbell-Meiklejohn et al., 2010). Conversely, activity in the striatum decreases when individuals' opinions are out of line with others, and this signal predicts subsequent conformity (Klucharev et al., 2009). Receptivity to peer influence in adolescence also appears to be strongly tied to the reward system (Casey et al., 2008a; Steinberg, 2008), and the VS in particular (Chein et al., 2010). These neural responses in the VS may track positive feelings, or may track salience of the incoming social signals more broadly, which are then integrated in VMPFC. Indeed, the response of the amygdala, another key limbic structure thought to detect salience, to persuasive smoking-cessation messages, has been shown to predict smokers' quitting outcomes (Jasinska et al., 2012).

This constellation of regions may also be of particular practical interest, given that patterns of activity in VMPFC have been shown to predict purchase decisions (Knutson et al., 2007), and other preference decisions, even when exposure to the choice objects is passive (i.e., when no explicit value judgment or purchasing decisions are required) (Tusche et al., 2010). Furthermore, signals in these regions also predict individual health behavior change over the course of weeks (Falk et al., 2010) or months (Falk et al., 2011), and population level behavior change in response to persuasive messages (Falk et al., 2012) and other socially relevant stimuli (Berns and Moore, 2012).

In sum, we propose that, as a natural extension of its role in integrating value and reward signals and motivating goal pursuit, the VS-VMPFC circuit also plays an integral role in adherence to social group norms and in responding to normative social influences more broadly. One explanation is that activity within this system may reflect the hedonic value of conformity to normative influences and the potential for rewards conferred by social acceptance. Such signals should positively reinforce future susceptibility to normative social influences, in accordance with the pleasurable feelings that arise from close social bonds (Lieberman and Eisenberger, 2009).

\section{SOCIAL PUNISHMENT AND INFLUENCE: NEUROIMAGING EVIDENCE}

Just as conforming to social norms leads to social rewards, not adhering to social norms can lead to ostracism and exclusion, a powerful form of social punishment. This phenomenon has been well documented in developmental psychological studies of person-group misfit demonstrating that children whose behavior deviates from group norms are more likely to be rejected and disliked (Wright et al., 1986; Boivin et al., 1995; Stormshak et al., 1999; Chen et al., 2003; Juvonen and Gross, 2005). In fact, Juvonen and Gross (2005) argue that one function of social exclusion or threats of rejection is to limit group deviance, and increase adherence to social norms. Of relevance to the argument that exclusion serves to limit group deviance, following exclusion experiences, people actively attempt to mitigate psychological consequences of exclusion by seeking out (DeWall et al., 2009) and working to regain social connection (Williams and Sommer, 1997; Maner et al., 2007; DeWall et al., 2008) through increased conformity (Williams et al., 2000; DeWall, 2010). Importantly, exclusion need not be experienced directly to have strong effects; for example, witnessing others be excluded can also be a powerful motivator to comply with perceived group norms (Juvonen and Galván, 2009), a phenomenon known as jeer pressure (Janes and Olson, 2000). Hence susceptibility to social exclusion may be increased for those who are most sensitive to the costs of exclusion, even in the absence of a particular rejection or exclusion stimulus.

What, then, determines the costliness of exclusion? Given the centrality of social bonds for human survival, humans have developed strong biological alarm systems thought to reduce the likelihood of isolation (Cacioppo et al., 2002; Hawkley et al., 2003, 2010; Peters et al., 2011; Eisenberger, 2012). A key component of this biological alarm system is the brain's response to rejection or threats of rejection. It has been theorized that the system for detecting the pain of social exclusion evolved out of the system for detecting physical pain (Panksepp et al., 1978; Eisenberger et al., 2003; Eisenberger, 2012). As noted above, brain regions and neurotransmitters that process physical pain are also thought to process social pain.

Consistent with a relational theory of social influence, neuroimaging studies of conformity have also found that failure 
to conform is associated with increased activity in dorsal anterior cingulate cortex (dACC) (Klucharev et al., 2009) and that changing one's opinion when it does not originally conform to the group is associated with activity in dACC and anterior insula (Berns et al., 2010). This pattern of activity may reflect calculations over the psychological (and physiological) cost of non-conformity. As such, these data are consistent with the idea that social exclusion may deter future deviations from group norms by highlighting the salient aversiveness of exclusion for the target of exclusion (Juvonen and Gross, 2005). In this way, neural systems that are sensitive to threats of social pain underpin social learning that brings individuals back in line with group norms.

Individuals vary, however, in the sensitivity of their neural response to social pain (DeWall et al., 2012) and its consequences. For example, heightened reactivity in social pain regions during exclusion is associated with individual differences in negative affect, risk of depression in adolescents (Masten et al., 2011), and increased inflammatory responses to social stressors (Slavich et al., 2010). Those individuals who are more sensitive to rejection, or feel the greatest unmet social needs in social interactions, may be more responsive to social influence (Juvonen and Galván, 2008, 2009). Specifically, individuals more sensitive to rejection may be: (1) more motivated to restore social status following an experience of social exclusion; and (2) more motivated to comply with perceived normative social influences in order to preemptively avoid exclusion as experienced in the past or as witnessed with others as victims. Consistent with this idea, developmental studies have observed that susceptibility to peer norms in childhood covaries with the extent to which youth are distressed by exclusion (Juvonen and Galván, 2009). Understanding the mechanisms underlying these individual differences would be greatly enhanced by identifying the neurochemical systems involved in the regulation of responses to exclusion. One way to probe these systems is through measuring variation in the genes that regulate the underlying brain systems.

\section{PROBING THE GENETIC BASIS OF INDIVIDUAL DIFFERENCES: THE IMAGING GENETICS APPROACH}

Extensive evidence from human genetics suggests that, in addition to influencing physical characteristics and physiology, genetic variation also accounts for individual differences in complex behavioral traits (Plomin et al., 1994). Individuals vary greatly in how susceptible they are to the social environment, including both social reward and social punishment (Carver and White, 1994). Investigation of the genetic bases of individual differences in sensitivity to social influences or in any other behavioral trait is challenging, however, in part because the path from genes to behavior is long and complex [for reviews, see (Burmeister et al., 2008; Way and Gurbaxani, 2008)]. Imaging genetics mitigates some of these challenges. Imaging genetics integrates neuroimaging and genetics to assess the impact of genetic variation on brain function and structure, instead of attempting to link genetic variation directly to the more distal behavioral or clinical phenotype (Hariri and Weinberger, 2003; Hariri et al., 2006). Imaging genetics reduces the complexity inherent in linking genes and behavior by focusing on neuroimaging endophenotypes (or intermediate phenotypes), which are postulated to lie closer in the biological pathway to the genes than behavioral phenotypes (Gottesman and Gould, 2003; Bearden and Freimer, 2006; Cannon and Keller, 2006). In particular, genetic variation in neurochemical systems may critically modulate neural and behavioral reactivity to both positive and negative social cues and thus in some cases serve as a common pathway contributing to individual differences in susceptibility to social influences (Figure 1 and Table 1). For example, elements of both the brain's reward and pain networks are known to detect salience and motivational relevance in response to both appetitive and aversive cues, and may have common genetic moderators. Thus, in the following sections, we review evidence for the involvement of different genetic variants in increasing the sensitivity of the reward and punishment systems separately, and conclude with a more integrative perspective suggesting that many of the genetic variants in question may sensitize both systems in parallel (Table $\mathbf{1}$ ).

\section{GENETIC MODERATORS OF SOCIAL INFLUENCE: PATHWAYS THROUGH SOCIAL REWARDS}

One function of the brain's reward system is to encode the expected value of stimuli, and to reinforce behaviors linked to positive experience (Berridge, 2012). The paradigmatic neurotransmitter within the reward system is dopamine. Dopamine is key in several types of learning processes, where reinforcing effects presumably stem from dopamine's role in mediating natural rewards. For example, VS activity increases when receiving a positive social evaluation just as it does when receiving monetary rewards (Izuma et al., 2008; Yacubian and Buchel, 2009), indicating that there is a common neural currency across rewards (Montague and Berns, 2002). Likewise, nearly all drugs of abuse increase levels of dopamine in the VS (Di Chiara and Imperato, 1988), which is thought to be critically involved in the reinforcing and addictive effects of drugs. Dopamine release in the VS as well as the PFC is thought to heighten the incentive salience of a stimulus (Berridge, 2012). Individuals who are more sensitive to such signals may perceive more subjective value and have more positive outcome expectancies for equivalent hedonic inputs, including anticipated social rewards (Caldu and Dreher, 2007). As such, these individuals may be more susceptible to persuasion and normative social influence when conforming is expected to produce social rewards.

Support for this hypothesized dopaminergic role in social influence comes from a study where synaptic dopamine levels were increased pharmacologically (Campbell-Meiklejohn et al., 2012). Methylphenidate, commonly known as Ritalin, exerts its primary pharmacological effect by inhibiting the reuptake of dopamine by the dopamine transporter (Solanto, 1998; Volkow et al., 2001). Administration of methylphenidate, compared to a placebo control, led to increased conformity to group opinion in healthy adults. Both placebo and experimental participants altered their behavior in response to large discrepancies between self and group ratings; however, methylphenidate significantly amplified conformity when the social influence manipulation was more subtle (i.e., when ratings were moderately discrepant from the group). Although the neural or psychological mechanism by which this conformity effect occurred is unclear, one hypothesis would be that the increases in 
Table 1 | Summary of genetic variants implicated in the modulation of neural and behavioral sensitivity to social influences.

\begin{tabular}{|c|c|c|c|c|}
\hline Polymorphism & Gene & Putative cellular effect & $\begin{array}{l}\text { Main reported neural } \\
\text { effect }\end{array}$ & $\begin{array}{l}\text { Emerging evidence of differential } \\
\text { susceptibility }\end{array}$ \\
\hline DAT 3' VNTR & $\begin{array}{l}\text { Dopamine transporter } \\
\text { (SLC6A3) }\end{array}$ & $\begin{array}{l}\text { 9-repeat allele, lower gene } \\
\text { expression }\end{array}$ & $\begin{array}{l}\text { Increased striatal reactivity } \\
\text { to reward-related stimuli }\end{array}$ & $\begin{array}{l}\text { Increased paralimbic reactivity } \\
\text { during conflict tasks }\end{array}$ \\
\hline COMT val ${ }^{158}$ met & $\begin{array}{l}\text { Catechol-O-methyl- } \\
\text { transferase } \\
(\text { COMT) }\end{array}$ & $\begin{array}{l}\text { Met allele, less enzyme } \\
\text { activity, higher synaptic } \\
\text { dopamine }\end{array}$ & $\begin{array}{l}\text { Met allele associated with } \\
\text { greater neural activity to } \\
\text { reward-related stimuli }\end{array}$ & $\begin{array}{l}\text { Met allele associated with greater } \\
\text { anxiety, greater neural activity } \\
\text { during negative emotion process- } \\
\text { ing, and greater pain reactivity }\end{array}$ \\
\hline MAOA-uVNTR & $\begin{array}{l}\text { Monoamine Oxidase A } \\
\text { (MAOA) }\end{array}$ & $\begin{array}{l}\text { Low expression allele, } \\
\text { reduced gene expression }\end{array}$ & $\begin{array}{l}\text { Low expression allele } \\
\text { greater paralimbic reactivity } \\
\text { to negative stimuli }\end{array}$ & $\begin{array}{l}\text { Some evidence for greater sensitiv- } \\
\text { ity to positive stimuli as well }\end{array}$ \\
\hline A118G & $\mu$-Opioid Receptor (OPRM1) & $\begin{array}{l}\text { G allele associated with } \\
\text { reduced gene expression }\end{array}$ & $\begin{array}{l}\text { Increased paralimbic } \\
\text { reactivity to negative stimuli }\end{array}$ & $\begin{array}{l}\text { Increased activation in } \\
\text { reward-related areas to reward and } \\
\text { rewarding cues }\end{array}$ \\
\hline 5-HTTLPR & $\begin{array}{l}\text { Serotonin transporter } \\
\text { (SLC6A4) }\end{array}$ & $\begin{array}{l}\text { Short allele decreased gene } \\
\text { expression in lymphoblasts }\end{array}$ & $\begin{array}{l}\text { Increased amygdala } \\
\text { reactivity to negative stimuli }\end{array}$ & $\begin{array}{l}\text { Increased left lateralized neural } \\
\text { activity in response to positive } \\
\text { stimuli }\end{array}$ \\
\hline
\end{tabular}

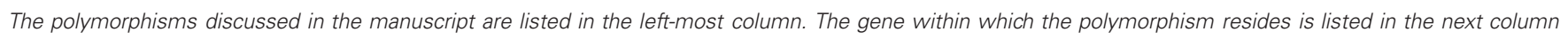

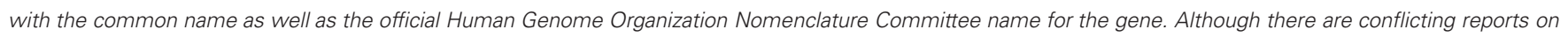
the cellular effect of each polymorphism, the most widely accepted effects are listed. In the fourth column, the listed neural effect is the most replicated finding.

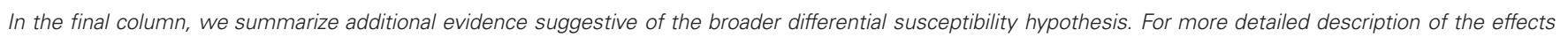
see text.

dopamine led to an assignment of greater value to the opinions of the group. This account is consistent with studies in other domains where increases in dopamine elicited by methylphenidate heighten the incentive salience of stimuli (Volkow et al., 2002, 2004).

As a complement to such pharmacological manipulations of the dopamine levels in the brain, the effects of naturally occurring variability in dopamine transporter function can also be assessed with an imaging genetics approach. The most studied variant in the dopamine transporter gene (SLC6A3) lies in the $3^{\prime}$ untranslated region of the gene. This polymorphism consists of a 40 base-pair segment that is repeated multiple times (Vandenbergh et al., 1992). The most common alleles consist of 9- and 10-repeats. Although not universally replicated, the general consensus is that the 9-repeat allele is associated with reduced dopamine transporter expression [(Fuke et al., 2001; VanNess et al., 2005); but see (Pinsonneault et al., 2011)], which is likely to lead to higher synaptic dopamine levels in response to a stimulus. The 9-repeat allele has been associated with greater striatal reactivity in a variety of reward-related tasks (Forbes et al., 2009; Nikolova et al., 2011; Zhong et al., 2012), particularly those that involve the anticipation of reward (Dreher et al., 2009; Franklin et al., 2009, 2011; Aarts et al., 2010). Consistent with these reward-related effects being mediated by higher extracellular dopamine levels, the 9-repeat allele is associated with greater dopamine release in the VS during cigarette smoking (Brody et al., 2006). In a situation requiring adjustment to social norms, the 9-repeat allele is likely to amplify the salience of the information about the opinions of the social group and give them greater value.

Synaptic levels of dopamine, particularly in the PFC, are also regulated by the enzyme catechol-O-methyl-transferase (COMT) (Karoum et al., 1994; Yavich et al., 2007), which we suggest is also likely involved in moderating the neural processes underlying social influence. Within the coding region of the COMT gene, there is a polymorphism that results in a substitution of the amino acid valine by methionine ( $\left.\mathrm{Val}{ }^{158} \mathrm{Met}\right)$. This substitution affects activity of the enzyme such that homozygotes for the val allele have $40 \%$ greater enzymatic activity than homozygotes for the met allele (Chen et al., 2004). This greater COMT activity is then associated with increased metabolism of dopamine, leading to lower synaptic dopamine levels in val/val individuals compared to met carriers.

Just as was reported with the dopamine transporter, genetic variation associated with greater extracellular dopamine is associated with greater VS response to reward anticipation (Yacubian et al., 2007; Dreher et al., 2009). Because of the relatively greater impact of COMT on prefrontal dopamine signaling than striatal signaling (Yavich et al., 2007), these associations between COMT Val ${ }^{158}$ Met and striatal activity are likely to be mediated by top-down influences from the PFC. Accordingly, the COMT met allele is also associated with greater prefrontal activity during reward anticipation (Yacubian et al., 2007) and VMPFC activation during reward receipt (Dreher et al., 2009). 
In line with the model we have been developing here, there is preliminary evidence that VMPFC activity is associated with memory for socially relevant messages (Langleben et al., 2009), and that COMT Val ${ }^{158}$ Met may be involved in social influence related processes in response to such messages (Falcone et al., 2011).

In addition to the genes involved in regulating synaptic levels of dopamine, there is also variation in the genes coding for dopamine receptors. These variants appear to act in concert with those in the DAT and COMT genes to affect reward-related processing (Forbes et al., 2009; Nikolova et al., 2011). Therefore, they are also likely to impact social influence processes. For example, in a study of social influence, young adults carrying at least one copy of the dopamine receptor dopamine receptor 4 (DRD4) 7-repeat allele conformed more to the drinking behavior of confederates than non-carriers of the allele (Larsen et al., 2010). Such effects are also consistent with observed covariation between rapid development of the brain's reward system during adolescence and increased susceptibility to social influence during this period (Steinberg, 2008; Spear, 2009; Galván, 2010; Albert and Steinberg, 2011). In particular, during adolescence, the dopaminergic system, and the VS in particular, show increased responsiveness to rewards (Galván et al., 2006; Galván, 2010). However, there are individual differences in the magnitude of such responsiveness (Galván, 2010), which may be driven in part by genetic modulators of the reward system. Furthermore, reward responses in the adolescent brain are amplified in the presence of peers (Chein et al., 2010), suggesting social modulation of these processes, which may also interact with genetic variants to produce more or less sensitivity to social cues (Larsen et al., 2010).

\section{GENETIC MODERATORS OF SOCIAL INFLUENCE: PATHWAYS THROUGH SOCIAL PUNISHMENT}

Just as reward signals reinforce behavior, and may promote susceptibility to social influence when conforming leads to social rewards, social punishment reinforces avoidance of behaviors that lead to such punishments. As described earlier, social pain and signals of social rejection activate the dACC and anterior insula (Eisenberger et al., 2003; Kross et al., 2011), and may also be modulated by the VS (Masten et al., 2009). These same regions, along with the amygdala, are also activated when an individual's preferences do not conform to those of others (Klucharev et al., 2009; Berns et al., 2010), and appear to be involved in eliciting changes in these preferences. As such, genetic factors that make exclusion feel more costly or increase sensitivity to signals of potential social rejection may predispose individuals to avoid impending exclusion in an effort to avoid the sting of social punishment (Juvonen and Galván, 2009).

Although identification of genetic variants that affect activity within social rejection-related circuits is just beginning, initial studies have built on physical pain-social pain overlap theory (Eisenberger et al., 2005). For example, morphine is the prototypical pain killer (Price et al., 1985) and exerts its pharmacological action on the $\mu$-opioid receptor (Pert and Snyder, 1973). Consistent with the $\mu$-opioid receptor being critically involved in responsivity to pain, variation in the $\mu$-opioid receptor gene
(OPRM1) is associated with differences in sensitivity to physical pain. The most widely, though not universally (Klepstad et al., 2011), replicated finding is that the G allele of a polymorphism in exon 1 (A118G) of OPRM1 is associated with greater sensitivity to physical pain (Klepstad et al., 2004; Bruehl et al., 2008; Tan et al., 2008), as well as greater need of opioid analgesia during experimental pain (Fukuda et al., 2009), cancer pain (ReyesGibby et al., 2007), or post-surgical recovery pain (Sia et al., 2008).

With respect to the pain of social rejection, the OPRM1 G allele is also associated with greater self-reported dispositional concern and worry about social rejection (Way et al., 2009). These dispositional concerns over perturbing others are also manifest in the neural response to an actual experience of social exclusion. Carriers of the $G$ allele exhibited greater activity within the dACC and anterior insula when being excluded from an online ball-tossing game. Other studies using this ball-tossing game (Williams et al., 2000) and other methods (DeWall, 2010) to simulate exclusion have shown that exclusion leads to increases in conformity. Thus, the psychological and neural effects of the A118G polymorphism could increase the likelihood of conformity following specific exclusion episodes, as observed by Williams and colleagues (2000) and by (DeWall, 2010), or more generally by motivating individuals who have felt most affected by exclusion in the past to preemptively avoid such exclusion in the future by conforming to perceived normative social influences. Psychologically, a heightened concern over being rejected in $G$ allele carriers may increase the aversiveness of the discordance between their own preferences and those of others. This could potentially be mediated by their greater dACC and anterior insula reactivity at the neural level, as these are the same areas that show greater reactivity during social dissonance (Klucharev et al., 2009; Berns et al., 2010). Recent work from our group (Falk et al., in preparation) also suggests that increased neural activity in the social pain network during exclusion predicts later susceptibility to social influence in adolescence.

In addition to possessing a high concentration of $\mu$-opioid receptors (Zubieta et al., 1999), the dACC and anterior insula also have a high concentration of the enzyme monoamine oxidase A (MAOA) (Ginovart et al., 2005). This enzyme is critical for breaking down serotonin and dopamine (Shih et al., 1999), which are important regulators of neural activity in these paralimbic areas, and are proposed here to be key mediators of effects of conformity and normative social influence. The promoter region of the $M A O A$ gene harbors a repeat polymorphism (MAOA-uVNTR) that affects gene expression (Sabol et al., 1998) or is in close association (i.e., linkage disequilibrium) with a functional polymorphism that affects expression (Pinsonneault et al., 2006).

The MAOA-uVNTR is associated with structural differences in the dACC (Meyer-Lindenberg et al., 2006) as well as functional differences in this region on several cognitive tasks (Fan et al., 2003; Meyer-Lindenberg et al., 2006; Buckholtz et al., 2008). This polymorphism is also associated with differential neural activation during exclusion from the on-line ball-tossing game in the precise portion of the $\mathrm{AACC}$ that is correlated with self-reported distress to the exclusion experience (Eisenberger et al., 2007). 
The same genotype associated with greater dACC reactivity was also associated with greater self-reported interpersonal hypersensitivity in these participants. This greater MAOA-uVNTR-related sensitivity to others at both the psychological and neural levels may increase the dissonance felt when not in conformity with the group and thereby increase the probability of conforming.

Further evidence for a role of the serotonin system in social influence and persuasion processes comes from a study of genetic variation in the serotonin transporter gene. The serotonin transporter is best known as the target of drugs like Prozac (fluoxetine) and other serotonin reuptake inhibitors (Wong et al., 1995), which are powerful modulators of amygdala activity (Arce et al., 2008). Intron 2 of the serotonin transporter gene (SLC6A4) harbors an insertion/deletion polymorphism (serotonin transporter intron 2, or STin2), containing 9, 10, 11, or 12 copies of a 17 basepair repeat element (Lesch et al., 1994; Ogilvie et al., 1996). The 12-repeat allele has been shown to be more efficiently transcribed than the 10-repeat allele, using a reporter-gene expression assay in vitro (Fiskerstrand et al., 1999), demonstrating that STin2 is a functional polymorphism.

In a study of persuasive communication amongst smokers trying to quit, the 10-repeat allele was associated with greater amygdala activity when viewing smoking cessation messages (Jasinska et al., 2012). Furthermore, the magnitude of this amygdala activity predicted quitting behavior, significantly mediating the relationship between the STin 2 polymorphism and post-intervention quitting outcome. Thus, it appears that genetic variation can heighten the salience of the persuasive messages. These data provide intriguing support of the framework proposed here-that genetic variants influence neural circuits coding received or anticipated social reward and punishment, which can then impact behavior. These findings are consistent with separate work showing that when making loss decisions under risk in a behavioral economics task, the 10-repeat allele is associated with both greater amygdala activity (Zhong et al., 2009) and greater valuation of losses (Zhong et al., 2012). As more studies integrate imaging, genetics, and behavioral outcomes in a similar manner, a critical question to resolve will be the precise mechanisms by which these processes interact.

\section{DIFFERENTIAL SUSCEPTIBILITY AND SALIENCE DETECTION}

Up to this point, this this Hypothesis has primarily focused on genetic variation affecting sensitivity to a particular hedonic valence, either social reward or social punishment. However, an emerging consensus from psychological genetic studies is that alleles conferring greater sensitivity to social stressors like rejection may also confer greater sensitivity to positively valenced stimuli such as social reward or support. This has been termed biological sensitivity to context (Boyce and Ellis, 2005), social sensitivity (Way and Gurbaxani, 2008; Way and Taylor, 2010), or differential susceptibility to the environment (Belsky and Pluess, 2009). For example, the G allele of the A118G OPRM1 polymorphism that was found to be associated with greater sensitivity to social rejection (Way et al., 2009) has also been associated with greater approach to appetitive stimuli (Wiers et al., 2009) as well as greater response to rewarding stimuli. G allele carriers have greater striatal dopamine response to alcohol (Ramchandani et al., 2010) as well as greater VS and VMPFC activation in response to alcohol cues (Filbey et al., 2008). G allele carriers also report greater subjective reinforcement following drinking alcohol in the laboratory (Ray and Hutchison, 2004) or in daily life (Ray et al., 2010). Thus, the G allele may confer greater sensitivity to both social rewards and social punishment, and the $\mathrm{G}$ allele may therefore increase social conformity by both increasing the hedonic value of conforming as well as increasing the aversiveness of non-conformity.

Similar effects have been seen for the COMT Val ${ }^{158}$ Met polymorphism. The met allele which was discussed here as being associated with greater reward-related neural activity has also been associated with greater anxious-related personality traits, anxiety disorders, and neural activity during negative emotion processing (Mier et al., 2009). The COMT Val ${ }^{158}$ Met polymorphism also plays a prominent role in physical pain processing, with the met allele generally (Kambur and Mannisto, 2010; Belfer and Segall, 2011), though by no means exclusively (Schmahl et al., 2012), associated with greater pain reactivity. Therefore, it would be expected that the met allele could also confer greater conformity by heightening the salience of cues of social rejection.

With respect to the dopamine transporter, there are preliminary indications that it may also function in a differentially susceptible manner. The 9-repeat allele that was associated with greater ventral striatal response to reward also shows greater ACC reactivity in a working memory task (Bertolino et al., 2006) and in an interference task (Brown et al., 2010). Though speculative, this greater ACC activity associated with the 9-repeat allele could heighten the salience of other stimuli processed by the ACC, such as cues of exclusion, and thereby increase conformity.

Finally, the serotonin transporter represents one of the most prominent examples of differential susceptibility stemming from genetic variation. The STin2 polymorphism in combination with another polymorphism in the serotonin transporter gene, the serotonin transporter gene-linked polymorphic region (5HTTLPR), which contains short and long alleles, has been found to moderate responsivity to the early caregiving environment in a differentially susceptible manner (Heils et al., 1996; Lesch et al., 1996). Individuals with the 10-repeat allele of the STin2 as well as the short allele of the 5-HTTLPR show the greatest levels of aggression and non-compliant behavior when exposed to poor parenting, but the lowest levels of such behavior when given nurturing parenting (Sulik et al., 2012). This pattern has also been seen in other studies of the 5-HTTLPR. Thus, although they are more vulnerable to depression in harsh, stressful life conditions, individuals with the short allele also benefit more from protective, nurturing environments, in which their risk of depressive symptoms is actually lower than the risk for individuals with two copies of the long allele (Caspi et al., 2003; Eley et al., 2004; Taylor et al., 2006). At the neural level, some evidence suggests that short allele carriers (compared to long/long individuals) show increased left lateralized neural activity in response to positive, compared to neutral inputs (Canli et al., 2005). Although less well studied, there is evidence that the MAOA-uVNTR may also function in a differentially susceptible manner with the low expression alleles conferring greater sensitivity to both negative and positive stimuli as well as positive ones (Belsky and Pluess, 2009). 
An important question for future research is the mechanism(s) by which such differential susceptibility is occurring. The imaging genetics approach is uniquely positioned to address this issue. There are two different models that could account for this effect. The first is that the neurochemical systems affected by the genetic variants discussed in this Hypothesis innervate both the social reward and social pain networks and thereby modulate their activity. Accordingly, the dopamine system exerts a powerful influence over the dACC (Vollenweider et al., 1998) in addition to its paradigmatic role in regulating VS activity. Similarily, the $\mu$-opioid receptor is highly concentrated in the ventral tegmental area dopamine cells and the VS (Spanagel et al., 1992; Svingos et al., 2001) in addition to the dACC and insula where it is regulating pain responses. Likewise, the serotonin system heavily innervates the VS (Way et al., 2007) and has prominent role in reward processing (Kranz et al., 2010). Presumably then, genetic variants in these neurochemical systems will have modulatory effects on both the social pain and social reward networks. Thus, the same variant would potentially increase reactivity in both pathways, leading to greater neural response to cues of social reward and signals of social rejection.

An alternative model is that the brain areas discussed in this Hypothesis as dedicated to processing a particular hedonic valence (e.g., VS: reward; dACC: social pain) may in fact be processing salience. In support of this model, the ACC and insula have been found to record a prediction error for both rewards and punishments (Metereau and Dreher, 2012). Similarly, the VS has also been found to be activated for anticipation of aversive outcomes (Jensen et al., 2003; Zink et al., 2003, 2004, 2006; Seymour et al., 2004; Menon et al., 2007) and physical pain (Becerra et al., 2001; Baliki et al., 2010). Furthermore, the amygdala and striatum have been associated with independence (failure to conform) when wrong information is provided by peers (Berns et al., 2005), suggesting that these regions may signal the salience of nonconformity. Therefore, the genetic variants discussed herein could affect social conformity by affecting the overall salience attributed to a social stimulus. In accord with this, dopamine neuron activity has been shown to code for both aversive and appetitive signals (Matsumoto and Hikosaka, 2009) and so genetic variants affecting dopaminergic activity could affect salience detection. Likewise, serotonin neurons have been shown to be involved in both reward- and punishment-related processing (Miyazaki et al., 2012). Future research attending to subareas of the brain structures described here, such as the dACC, may uncover patterns of activity dedicated to social reward-related processing, social painrelated processing, and salience. Paradigms that more clearly and unambiguously distinguish between the reward and punishment aspects of social influence will be critical in the larger ongoing endeavor of understanding the neural and neurochemical bases of reinforcement processing, and social influence on behavior more broadly.

\section{INTEGRATIVE IMAGING GENETICS APPROACH}

In this Hypothesis, we review a growing body of evidence suggesting that susceptibility to normative influences shares its neurobiological underpinnings with, and can be conceptualized in parallel with, sensitivity to social rewards and punishments. We further argue that this sensitivity to social reward and punishment is likely to be moderated by shared genetic variation which produces differential sensitivity in the brain's reward and pain systems, respectively (Figure 1). In particular, building on theory and extant evidence examining sensitivity to the broader social environment, some genetic moderators are likely to affect the sensitivity of both systems through heightening responsiveness to all salient cues, including both positive and negative social cues. Finally, we propose that an integrative imaging genetics approach focusing on neural systems for reward and social pain and their genetic modulators is particularly well suited to the investigation of the neurobiological bases of individual differences in susceptibility to a range of normative social influence, including persuasion and peer pressure.

In closing, we note some challenges of the imaging genetics approach. Some of these challenges are inherent to mapping of behavioral phenotypes to their underlying causal genotypes [for reviews, see (Burmeister et al., 2008; Way and Gurbaxani, 2008)]. Early genetic studies focused on monogenic Mendelian traits, i.e., traits that are largely determined by a single genetic factor whose influence is fully manifested in each individual. But most behavioral phenotypes are thought to be polygenic (i.e., shaped by multiple genetic factors). In addition, the impact of any genetic variant on behavior may be modified by gene-gene interactions (epistasis). Consistent with this tendency, it is almost certainly the case that interactions between genetic systems reviewed, as well as interactions with other systems (e.g., the oxytocin system), exert both direct and indirect effects on susceptibility to social influence (e.g., by triggering dopaminergic responses). The impact of any given genetic variant is also subject to gene-environment interactions $(G \times E)$; in fact, growing evidence suggests that such $G \times$ E effects may be key to understanding many of the connections proposed in this review. Future research examining the hypotheses outlined herein in the context of normative influences, across multiple genes and their potential additive or interactive effects on the brain systems in question, will be of great interest moving forward. Additional challenges stem from integration of genotyping and neuroimaging-two techniques that can independently produce massive data-sets, and require careful and rigorous statistical analyses. And perhaps the most acute practical challenge of imaging genetics is the sample size required to obtain balanced genotype groups of even one genetic polymorphism, in order to examine its impact on the brain systems and behaviors of interest. As such, approaches that work from strong a priori hypotheses and select groups prospectively are likely to be most informative in advancing this research agenda.

\section{FUTURE DIRECTIONS}

In the current review, we offer hypothesized relationships between an initial set of brain systems that appear to be involved in processes relevant to social influence and genetic factors that modulate these systems. Despite the complexity and difficulty of linking gene variation to behavioral phenotypes, joint consideration of genes, neural systems and behavioral outcomes may provide insight that is not possible when considering 
any one of these systems in isolation. Future work that specifically links each of these levels of analysis, as well as pharmacological work that manipulates the functions of key neurotransmitters, may be particularly useful in elucidating the processes that lead to "the profound effects that groups exert on their members" (Asch, 1955), as well as the factors that lead individuals to be differentially susceptible to such effects.

\section{REFERENCES}

Aarts, E., Roelofs, A., Franke, B., Rijpkema, M., Fernandez, G., Helmich, R. C., and Cools, R. (2010). Striatal dopamine mediates the interface between motivational and cognitive control in humans: evidence from genetic imaging. Neuropsychopharmacology 35, 1943-1951.

Adcock, R. A., Thangavel, A., Whitfield-Gabrieli, S., Knutson, B., and Gabrieli, J. D. (2006). Reward-motivated learning: mesolimbic activation precedes memory formation. Neuron 50, 507-517.

Albert, D., and Steinberg, L. (2011). "Peer influences on adolescent risk behavior," in Inhibitory Control and Drug Abuse Prevention: From Research to Translation, eds M. T. Bardo, D. H. Fishbein, and R. Milich (New York, NY: Springer), 211-226.

Arce, E., Simmons, A. N., Lovero, K. L., Stein, M. B., and Paulus, M. P. (2008). Escitalopram effects on insula and amygdala BOLD activation during emotional processing. Psychopharmacology (Berl.) 196, 661-672.

Asch, S. E. (1955). Opinions and social pressure. Sci. Am. 193, 31-35.

Baliki, M. N., Geha, P. Y., Fields, H. L., and Apkarian, A. V. (2010). Predicting value of pain and analgesia: nucleus accumbens response to noxious stimuli changes in the presence of chronic pain. Neuron 66, 149-160.

Bearden, C. E., and Freimer, N. B. (2006). Endophenotypes for psychiatric disorders: ready for primetime? Trends Genet. 22, 306-313.

Becerra, L., Breiter, H. C., Wise, R., Gonzalez, R. G., and Borsook, D. (2001). Reward circuitry activation by noxious thermal stimuli. Neuron 32, 927-946.

Belfer, I., and Segall, S. (2011). COMT genetic variants and pain. Drugs Today (Barc.) 47, 457-467.

Belsky, J. and Pluess, M. (2009). Beyond diathesis stress: differential susceptibility to environmental influences. Psychol. Bull. 135, 885-908.

Berkman, E. T., and Lieberman, M. D. (2010). Approaching the bad and avoiding the good: lateral prefrontal cortical asymmetry distinguishes between action and valence. J. Cogn. Neurosci. 22, 1970-1979.

Berns, G. S., Capra, C. M., Moore, S., and Noussair, C. (2010). Neural mechanisms of the influence of popularity on adolescent ratings of music. Neuroimage 49, 2687-2696.

Berns, G. S., Chappelow, J., Zink, C. F., Pagnoni, G., Martin-Skurski, M. E., and Richards, J. (2005). Neurobiological correlates of social conformity and independence during mental rotation. Biol. Psychiatry 58, 245-253.

Berns, G. S., and Moore, S. E. (2012). A neural predictor of cultural popularity. J. Consum. Psychol. 22, 154-160.

Berridge, K. C. (2012). From prediciton error to incentive salience: mesolimbic computation of reward motivation. Eur. J. Neurosci. 35, 1124-1143.

Bertolino, A., Blasi, G., Latorre, V., Rubino, V., Rampino, A., Sinibaldi, L., and Dallapiccola, B. (2006). Additive effects of genetic variation in dopamine regulating genes on working memory cortical activity in human brain. J. Neurosci. 26, 3918-3922.

Boivin, M., Dodge, K. A., and Coie, J. D. (1995). Individual-group behavioral similarity and peer status in experimental play groups of boys: the social misfit revisited. J. Pers. Soc. Psychol. 69, 269-279.

Boyce, W. T., and Ellis, B. J. (2005). Biological sensitivity to context: I. An evolutionary-developmental theory of the origins and functions of stress reactivity. Dev. Psychopathol. 17, 271-301.

Brody, A. L., Mandelkern, M. A., Olmstead, R. E., Scheibal, D., Hahn, E., Shiraga, S., Zamora-Paja, E., Farahi, J., Saxena, S., London, E. D., and Mccracken, J. T. (2006). Gene variants of brain dopamine pathways and smoking-induced dopamine release in the ventral

\section{ACKNOWLEDGMENTS}

The authors wish to thank Steve Cole for helpful discussion of ideas outlined in this manuscript, as well as Francis Tinney and Matthew Brook O'Donnell for assistance with manuscript preparation. We also wish to thank the two reviewers for their helpful suggestions that have strengthened this manuscript. This work was made possible in part by a grant from the University of Michigan Injury Center.

caudate/nucleus accumbens. Arch. Gen. Psychiatry 63, 808-816.

Brown, A. B., Biederman, J., Valera, E. M., Doyle, A. E., Bush, G., Spencer, T., and Seidman, L. J. (2010). Effect of dopamine transporter gene (SLC6A3) variation on dorsal anterior cingulate function in attentiondeficit/hyperactivity disorder. Am J. Med. Genet. B Neuropsychiatr. Genet. 153B, 365-375.

Bruehl, S., Chung, O. Y., and Burns, J. W. (2008). The mu opioid receptor A118G gene polymorphism moderates effects of trait anger-out on acute pain sensitivity. Pain 139, 406-415.

Buckholtz, J. W., Callicott, J. H., Kolachana, B., Hariri, A. R., Goldberg, T. E., Genderson, M., Egan, M. F., Mattay, V. S., Weinberger, D. R., and MeyerLindenberg, A. (2008). Genetic variation in MAOA modulates ventromedial prefrontal circuitry mediating individual differences in human personality. Mol. Psychiatry 13, 313-324.

Burmeister, M., McInnis, M. G., and Zollner, S. (2008). Psychiatric genetics: progress amid controversy. Nat. Rev. Genet. 9, 527-540.

Cacioppo, J. T., Gardner, W. L., and Berntson, G. G. (1997). Beyond bipolar conceptualizations and measures: the case of attitudes and evaluative space. Pers. Soc. Psychol. Rev. 1, 3-25.

Cacioppo, J. T., Hawkley, L. C., Crawford, L. E., Ernst, J. M., Burleson, M. H., Kowalewski, R. B., Malarkey, W. B., Van Cauter, E., and Berntson, G. G. (2002). Loneliness and health: potential mechanisms. Psychosom. Med. 64, 407-417.

Caldu, X., and Dreher, J. C. (2007). Hormonal and genetic influences on processing reward and social information. Ann. N.Y. Acad. Sci. 1118 43-73.

Campbell-Meiklejohn, D. K., Bach, D. R., Roepstorff, A., Dolan, R. J., and Frith, C. D. (2010). How the opinion of others affects our valuation of objects. Curr. Biol. 20, 1165-1170.
Campbell-Meiklejohn, D. K., Simonsen, A., Jensen, M., Wohlert, V., Gjerloff, T., ScheelKruger, J., Moller, A., Frith, C. D., and Roepstorff, A. (2012). Modulation of social influence by methylphenidate. Neuropsychopharmacology 37, 1517-1525.

Canli, T., Omura, K., Haas, B. W., Fallgatter, A., Constable, R. T., and Lesch, K. P. (2005). Beyond affect: a role for genetic variation of the serotonin transporter in neural activation during a cognitive attention task. Proc. Natl. Acad. Sci. U.S.A. 102, 12224-12229.

Cannon, T. D., and Keller, M. C. (2006). Endophenotypes in the genetic analyses of mental disorders. Annu. Rev. Clin. Psychol. 2, 267-290.

Carver, C., and White, T. (1994). Behavioral inhibition, behavioral activation, and affective responses to impending reward and punishment: The BIS/BAS Scale. J. Pers. Soc. Psychol. 67, 319-333.

Casey, B. J., Getz, S., and Galván, A. (2008a). The adolescent brain. Dev. Rev. 28, 62-77.

Casey, B. J., Jones, R. M., and Hare, T. A. (2008b). The adolescent brain. Ann. N.Y. Acad. Sci. 1124, 111-126.

Caspi, A., Sugden, K., Moffitt, T. E., Taylor, A., Craig, I. W., Harrington, H., Mcclay, J., Mill, J., Martin, J., Braithwaite, A., and Poulton, R. (2003). Influence of life stress on depression: moderation by a polymorphism in the 5-HTT gene. Science 301, 386-389.

Chaiken, S., Liberman, A., Eagly, A. H., Uleman, J. S., and Bargh, J. A. (1989). Heuristic and Systematic Information Processing within and Beyond the Persuasion Context. New York, NY: Guilford Press.

Chein, J., Albert, D., O’Brien, L., Uckert, K., and Steinberg, L. (2010). Peers increase adolescent risk taking by enhancing activity in the brain's reward circuitry. Dev. Sci. 14, F1-F10.

Chen, J. S., Lipska, B. K., Halim, N., Ma, Q. D., Matsumoto, M., Melhem, 
S., Kolachana, B. S., Hyde, T. M., Herman, M. M., Apud, J., Egan, M. F., Kleinman, J. E., and Weinberger, D. R. (2004). Functional analysis of genetic variation in catechol-omethyltransferase (COMT): Effects on mRNA, protein, and enzyme activity in postmortem human brain. Am. J. Hum. Genet. 75, 807-821.

Chen, X., Chang, L., and He, Y. (2003). The peer group as a context: mediating and moderating effects on relations between academic achievement and social functioning in Chinese children. Child Dev. 74, 710-727.

Cialdini, R. B., and Goldstein, N. J. (2004). Social influence: compliance and conformity. Annu. Rev. Psychol. 55, 591-621.

Cunningham, W. A., and Zelazo, P. (2007). Attitudes and evaluations: a social cognitive neuroscience perspective. Trends Cogn. Sci. 11, 97-104.

Cunningham, W. A., Zelazo, P., Packer, D. J., and Van Bavel, J. J. (2007). The iterative reprocessing model: a multilevel framework for attitudes and evaluation. Soc. Cogn. 25, 736-760.

DeWall, C. N. (2010). Forming a basis for acceptance: excluded people form attitudes to agree with potential affiliates. Soc. Influence 5, 245-260.

DeWall, C. N., Baumeister, R. F., and Vohs, K. D. (2008). Satiated with belongingness? effects of acceptance, rejection, and task framing on self-regulatory performance. J. Pers. Soc. Psychol. 95, 1367-1382.

DeWall, C. N., Maner, J. K., and Rouby, D. A. (2009). Social exclusion and early-stage interpersonal perception: selective attention to signs of acceptance. J. Pers. Soc. Psychol. 96, 729-741.

DeWall, C. N., Masten, C. L., Powell, C., Combs, D., Schurtz, D. R., and Eisenberger, N. I. (2012). Do neural responses to rejection depend on attachment style? An fMRI study. Soc. Cogn. Affect. Neurosci. 7, 184-192.

Di Chiara, G., and Imperato, A. (1988). Drugs abused by humans preferentially increase synaptic dopamine concentrations in the mesolimbic system of freely moving rats. Proc. Natl. Acad. Sci. U.S.A. 85,5274

Dreher, J. C., Kohn, P., Kolachana, B., Weinberger, D. R., and Berman, K. F. (2009). Variation in dopamine genes influences responsivity of the human reward system. Proc. Natl. Acad. Sci. U.S.A. 106, 617-622.
Eagly, A., and Chaiken, S. (2007). The Advantages of an inclusive definition of attitude. Soc. Cogn. 25, 582-602.

Eagly, A. H., and Chaiken, S. (1993). The Psychology of Attitudes. Orlando, FL: Harcourt Brace Jovanovich College Publishers.

Eagly, A. H., and Chaiken, S. (2005). Attitude Research in the 21st Century: The Current State of Knowledge. Mahwah, NJ: Lawrence Erlbaum Associates Publishers.

Eisenberger, N., Lieberman, M., and Williams, K. (2003). Does rejection hurt? An fMRI study of social exclusion. Science 302, 290-292.

Eisenberger, N. I. (2012). The neural bases of social pain: evidence for shared representations with physical pain. Psychosom. Med. 74, 126-135.

Eisenberger, N. I., Lieberman, M. D., Williams, K. D., Forgas, J. P., and Van Hippel, W. (2005). "Why it hurts to be left out: The neurocognitive overlap between physical and social pain," in The Social Outcast: Ostracism, Social Exclusion, Rejection, and Bullying, eds K. D. Williams, J. P. Forgas, and W. von Hippel (New York, NY: Cambridge University Press), 109-127.

Eisenberger, N. I., Way, B. M., Taylor, S. E., Welch, W. T., and Lieberman, M. D. (2007). Understanding genetic risk for aggression: clues from the brain's response to social exclusion. Biol. Psychiatry 61, 1100-1108.

Eley, T. C., Sugden, K., Corsico, A., Gregory, A. M., Sham, P., Mcguffin, P., Plomin, R., and Craig, I. W. (2004). Gene-environment interaction analysis of serotonin system markers with adolescent depression. Mol. Psychiatry 9, 908-915.

Falcone, M., Jepson, C., Sanborn, P., Cappella, J. N., Lerman, C., and Strasser, A. A. (2011). Association of BDNF and COMT genotypes with cognitive processing of antismoking PSAs. Genes Brain Behav. 10, 862-867.

Falk, E. B., Berkman, E. T., and Lieberman, M. D. (2012). From neural responses to population behavior: neural focus group predicts population level media effects. Psychol. Sci. 23, 439-445.

Falk, E. B., Berkman, E. T., Mann, T., Harrison, B., and Lieberman, M. D. (2010). Predicting persuasioninduced behavior change from the brain. J. Neurosci. 30 8421-8424.

Falk, E. B., Berkman, E. T., Whalen, D., and Lieberman, M. D. (2011). Neural activity during health messaging predicts reductions in smoking above and beyond self-report. Health Psychol. 30, 177-185.

Fan, J., Fossella, J., Sommer, T., Wu, Y. H., and Posner, M. I. (2003). Mapping the genetic variation of executive attention onto brain activity. Proc. Natl. Acad. Sci. U.S.A. 100 7406-7411.

Filbey, F. M., Ray, L., Smolen, A., Claus, E. D., Audette, A., and Hutchison, K. E. (2008). Differential neural response to alcohol priming and alcohol taste cues is associated with DRD4 VNTR and OPRM1 genotypes. Alcohol. Clin. Exp. Res. 32, 1113-1123.

Fiskerstrand, C. E., Lovejoy, E. A., and Quinn, J. P. (1999). An intronic polymorphic domain often associated with susceptibility to affective disorders has allele dependent differential enhancer activity in embryonic stem cells. FEBS Lett. $458,171-174$

Forbes, E. E., Brown, S. M., Kimak, M., Ferrell, R. E., Manuck, S. B., and Hariri, A. R. (2009). Genetic variation in components of dopamine neurotransmission impacts ventral striatal reactivity associated with impulsivity. Mol. Psychiatry 14 60-70.

Franklin, T. R., Lohoff, F. W., Wang, Z., Sciortino, N., Harper, D., Li, Y., Jens, W., Cruz, J., Kampman, K., Ehrman, R., Berrettini, W. Detre, J. A., O'Brien, C. P., and Childress, A. R. (2009). DAT genotype modulates brain and behavioral responses elicited by cigarette cues. Neuropsychopharmacology 34 , 717-728.

Franklin, T. R., Wang, Z., Li, Y., Suh, J. J., Goldman, M., Lohoff, F. W., Cruz, J., Hazan, R., Jens, W., Detre, J. A., Berrettini, W., O’Brien, C P., and Childress, A. R. (2011). Dopamine transporter genotype modulation of neural responses to smoking cues: confirmation in a new cohort. Addict. Biol. 16, 308-322.

Fuke, S., Suo, S., Takahashi, N., Koike, H., Sasagawa, N., and Ishiura, S. (2001). The VNTR polymorphism of the human dopamine transporter (DAT1) gene affects gene expression. Pharmacogenomics J. 1 , 152-156.

Fukuda, K., Hayashida, M., Ide, S. Saita, N., Kokita, Y., Kasai, S., Nishizawa, D., Ogai, Y., Hasegawa, J., Nagashima, M., Tagami, M. Komatsu, H., Sora, I., Koga, H., Kaneko, Y., and Ikeda, K. (2009). Association between OPRM1 gene polymorphisms and fentanyl sensitivity in patients undergoing painful cosmetic surgery. Pain 147 , 194-201.

Galván, A. (2010). Adolescent development of the reward system. Front. Hum. Neurosci. 4:6. doi: 10.3389/neuro.09.006.2010

Galván, A., Hare, T. A., Parra, C. E., Penn, J., Voss, H., Glover, G., and Casey, B. J. (2006). Earlier development of the accumbens relative to orbitofrontal cortex might underlie risk-taking behavior in adolescents. J. Neurosci. 26, 6885-6892.

Ginovart, N., Meyer, J. H., Boovariwala, A., Hussey, D., Rabiner, E. A., Houle, S., and Wilson, A. A. (2005). Positron emission tomography quantification of andlsqb; 11Candrsqb;-harmine binding to monoamine oxidase- $\mathrm{A}$ in the human brain. J. Cereb. Blood Flow Metab. 26, 330-344.

Goldstein, N. J., Cialdini, R. B., and Griskevicius, V. (2008). A room with a viewpoint: using social norms to motivate environmental conservation in hotels. J. Consum. Res. 35, 472-482.

Gottesman, I. I., and Gould, T. D. (2003). The endophenotype concept in psychiatry: etymology and strategic intentions. Am. J. Psychiatry 160, 636-645.

Gray, J. A. (1987). The Psychology of Fear and Stress. New York, NY: Cambridge University Press.

Gray, J. A. (1990). Brain systems that mediate both emotion and cognition. Cogn. Emot. 4, 269-288.

Haber, S. N., and Knutson, B. (2010). The reward circuit: linking primate anatomy and human imaging. Neuropsychopharmacology 35 , 4-26.

Hare, T. A., Camerer, C. F., and Rangel, A. (2009). Self-control in decisionmaking involves modulation of the vmPFC valuation system. Science 324, 646-648.

Hare, T. A., Malmaud, J., and Rangel, A. (2011). Focusing attention on the health aspects of foods changes value signals in vmPFC and improves dietary choice. J. Neurosci. 31, 11077-11087.

Hariri, A. R., Drabant, E. M., and Weinberger, D. R. (2006). Imaging genetics: perspectives from studies of genetically driven variation in serotonin function and corticolimbic affective processing. Biol. Psychiatry 59, 888-897.

Hariri, A. R., and Weinberger, D. R. (2003). Imaging genomics. Br. Med. Bull. 65, 259-270.

Harmon-Jones, E., Lueck, L., Fearn, M., and Harmon-Jones, C. (2006). The effect of personal relevance and approach-related action expectation 
on relative left frontal cortical activity. Psychol. Sci. 17, 434-440.

Hawkley, L. C., Burleson, M. H., Berntson, G. G., and Cacioppo, J. T. (2003). Loneliness in everyday life: cardiovascular activity, psychosocial context, and health behaviors. J. Pers. Soc. Psychol. 85, 105-120.

Hawkley, L. C., Thisted, R. A., Masi, C. M., and Cacioppo, J. T. (2010). Loneliness predicts increased blood pressure: 5-year cross-lagged analyses in middle-aged and older adults. Psychol. Aging 25, 132-141.

Heils, A., Teufel, A., Petri, S., Stober, G., Riederer, P., Bengel, D., and Lesch, K. P. (1996). Allelic variation of human serotonin transporter gene expression. J. Neurochem. 66, 2621-2624.

Izuma, K., Saito, D. N., and Sadato, N. (2008). Processing of social and monetary rewards in the human striatum. Neuron 58, 284-294.

Janes, L. M., and Olson, J. M. (2000). Jeer pressure: the behavioral effects of observing ridicule of others. Pers. Soc. Psychol. Bull. 26, 474-485.

Jasinska, A. J., Chua, H. F., Ho, S. S., Polk, T. A., Rozek, L. S., and Strecher, V. J. (2012). Amygdala response to smoking-cessation messages mediates the effects of serotonin transporter gene variation on quitting. Neuroimage 60, 766-773.

Jensen, J., Mcintosh, A. R., Crawley, A. P., Mikulis, D. J., Remington, G., and Kapur, S. (2003). Direct activation of the ventral striatum in anticipation of aversive stimuli. Neuron 40, 1251-1257.

Juvonen, J., and Galván, A. (2008). "Peer influence in involuntary social groups: lessons from research on bullying," in Peer Influence Processes Among Youth, eds M. J. Prinstein and K. A. Dodge (New York, NY: Guilford Press), 225-244.

Juvonen, J., and Galván, A. (2009). "Bullying as a means to foster compliance," in Bullying, Rejection, and Peer Victimization: A Social Cognitive Neuroscience Perspective, ed M. Harris (New York, NY: Springer), 299-318.

Juvonen, J., and Gross, E. F. (2005). "The rejected and the bullied: lessons about social misfits from developmental psychology," in The Social Outcast: Ostracism, Social Exclusion, Rejection, and Bullying, eds K. D. Williams, J. P. Forgas, and W. Von Hippel (New York, NY: Psychology Press), 155-170.

Kambur, O., and Mannisto, P. T. (2010). Catechol O-Methyltransferase and pain. Int. Rev. Neurobiol. 95, 227-279.
Karoum, F., Chrapusta, S. J., and Egan, M. F. (1994). 3-Methoxytyramine is the major metabolite of released dopamine in the rat frontal cortex: reassessment of the effects of antipsychotics on the dynamics of dopamine release and metabolism in the frontal cortex, nucleus accumbens, and striatum by a simple two pool model. J. Neurochem. 63, 972-979.

Klepstad, P., Fladvad, T., Skorpen, F., Bjordal, K., Caraceni, A., Dale, O., Davies, A., Kloke, M., Lundstrom, S., Maltoni, M., Radbruch, L., Sabatowski, R., Sigurdardottir, V., Strasser, F., Fayers, P. M., Kaasa, S., Epcrc, and Res, E. A. P. C. (2011). Influence from genetic variability on opioid use for cancer pain: A european genetic association study of 2294 cancer pain patients. Pain 152, 1139-1145.

Klepstad, P., Rakvag, T. T., Kaasa, S., Holthe, M., Dale, O., Borchgrevink, P. C., Baar, C., Vikan, T., Krokan, H. E., and Skorpen, F. (2004). The $118 \mathrm{~A}>\mathrm{G}$ polymorphism in the human mu-opioid receptor gene may increase morphine requirements in patients with pain caused by malignant disease. Acta Anaesthesiol. Scand. 48, 1232-1239.

Klucharev, V., Hytonen, K., Rijpkema, M., Smidts, A., and Fernandez, G. (2009). Reinforcement learning signal predicts social conformity. Neuron 61, 140-151.

Klucharev, V., Smidts, A., and Fernandez, G. (2008). Brain mechanisms of persuasion: how 'expert power' modulates memory and attitudes. Soc. Cogn. Affect. Neurosci. 3, 353-366.

Knutson, B., Adams, C. M., Fong, G. W., and Hommer, D. (2001). Anticipation of increasing monetary reward selectively recruits nucleus accumbens. J. Neurosci. 21, 105.

Knutson, B., and Cooper, J. C. (2005). Functional magnetic resonance imaging of reward prediction. Curr. Opin. Neurol. 18, 411-417.

Knutson, B., and Greer, S. M. (2008). Anticipatory affect: neural correlates and consequences for choice. Philos. Trans. R. Soc. Lond. B Biol. Sci. 363, 3771-3786.

Knutson, B., Rick, S., Wimmer, G. E., Prelec, D., and Loewenstein, G. (2007). Neural predictors of purchases. Neuron 53, 147-156.

Kranz, G. S., Kasper, S., and Lanzenberger, R. (2010). Reward and the serotonergic system. Neuroscience 166, 1023-1035.

Kross, E., Berman, M. G., Mischel, W., Smith, E. E., and Wager, T.
D. (2011). Social rejection shares somatosensory representations with physical pain. Proc. Natl. Acad. Sci. U.S.A. 108, 6270-6275.

Langleben, D. D., Loughead, J. W., Ruparel, K., Hakun, J. G., BuschWinokur, S., Holloway, M. B. Strasser, A. A., Cappella, J. N., and Lerman, C. (2009). Reduced prefrontal and temporal processing and recall of high "sensation value" ads. Neuroimage 46, 219-225.

Larsen, H., Van Der Zwaluw, C. S., Overbeek, G., Granic, I., Franke, B., and Engels, R. C. (2010). A variable-number-of-tandemrepeats polymorphism in the dopamine $\mathrm{D} 4$ receptor gene affects social adaptation of alcohol use: investigation of a gene-environment interaction. Psychol. Sci. 21, 1064-1068

Lesch, K. P., Balling, U., Gross, J., Strauss, K., Wolozin, B. L., Murphy, D. L., and Riederer, P. (1994), Organization of the human serotonin transporter gene. J. Neural Transm. Gen. Sect. 95, 157-162.

Lesch, K. P., Bengel, D., Heils, A., Sabol, S. Z., Greenberg, B. D., Petri, S., Benjamin, J., Muller, C. R., Hamer, D. H., and Murphy, D. L. (1996) Association of anxiety-related traits with a polymorphism in the serotonin transporter gene regulatory region. Science 274, 1527-1531.

Lieberman, M. D., and Eisenberger, N. I. (2009). Pains and pleasures of social life. Science 323, 890-891.

Maner, J. K., DeWall, C. N., Baumeister, R. F., and Schaller, M. (2007). Does social exclusion motivate interpersonal reconnection? Resolving the "porcupine problem". J. Pers. Soc. Psychol. 92, 42-55.

Mason, M. F., Dyer, R. G., and Norton, M. I. (2009). Neural mechanisms of social influence. Organ. Behav. Hum. Decis. Process. 110, 152-159.

Masten, C., Eisenberger, N., and Borofsky, L. (2009). Neural correlates of social exclusion during adolescence: understanding the distress of peer rejection. Soc. Cogn. Affect. Neurosci. 4, 143-157.

Masten, C. L., Eisenberger, N. I., Borofsky, L. A., McNealy, K., Pfeifer, J. H., and Dapretto, M. (2011). Subgenual anterior cingulate responses to peer rejection: a marker of adolescents' risk for depression. Dev. Psychopathol. 23, 283-292.

Matsumoto, M., and Hikosaka, O. (2009). Two types of dopamine neuron distinctly convey positive and negative motivational signals. Nature 459, U837-U841.
McClure, S. M., Li, J., Tomlin, D., Cypert, K., Montague, L., and Montague, P. (2004a). Neural correlates of behavioral preference for culturally familiar drinks. Neuron 44, 379-387.

McClure, S. M., York, M. K., and Montague, P. R. (2004b). The neural substrates of reward processing in humans: the modern role of FMRI. Neuroscientist 10, 260-268.

Menon, M., Jensen, J., Vitcu, I., GraffGuerrero, A., Crawley, A., Smith, M. A., and Kapur, S. (2007). Temporal difference modeling of the bloodoxygen level dependent response during aversive conditioning in humans: effects of dopaminergic modulation. Biol. Psychiatry 62, 765-772.

Metereau, E., and Dreher, J. C. (2012). Cerebral correlates of salient prediction error for different rewards and punishments. Cereb. Cortex. doi: 10.1093/cercor/bhs037. [Epub ahead of print].

Meyer-Lindenberg, A., Buckholtz, J. W., Kolachana, B., Hariri, A. R., Pezawas, L., Blasi, G., Wabnitz, A., Honea, R., Verchinski, B., Callicott, J. H., Egan, M., Mattay, V., and Weinberger, D. R. (2006). Neural mechanisms of genetic risk for impulsivity and violence in humans. Proc. Natl. Acad. Sci. U.S.A. 103, 6269-6274.

Mier, D., Kirsch, P., and MeyerLindenberg, A. (2009). Neural substrates of pleiotropic action of genetic variation in COMT: a meta-analysis. Mol. Psychiatry 15, 918-927.

Miyazaki, K., Miyazaki, K. W., and Doya, K. (2012). The role of serotonin in the regulation of patience and impulsivity. Mol. Neurobiol. 45, 213-224.

Montague, P. R., and Berns, G. S (2002). Neural economics and the biological substrates of valuation. Neuron 36, 265-284.

Nikolova, Y. S., Ferrell, R. E., Manuck, S. B., and Hariri, A. R. (2011). Multilocus genetic profile for dopamine signaling predicts ventral striatum reactivity. Neuropsychopharmacology 36, 1940-1947.

Ogilvie, A. D., Battersby, S., Bubb, V. J., Fink, G., Harmar, A. J., Goodwim, G. M., and Smith, C. A. (1996). Polymorphism in serotonin transporter gene associated with susceptibility to major depression. Lancet 347, 731-733

Panksepp, J., Herman, B., Conner, R., Bishop, P., and Scott, J. P. (1978). The biology of social attachments: opiates alleviate separation distress. Biol. Psychiatry 13, 607-618. 
Pert, C. B., and Snyder, S. H. (1973). Opiate receptor: demonstration in nervous tissue. Science 179, 1011-1014.

Peters, E., Riksen-Walraven, J. M., Cillessen, A. H., and De Weerth, C. (2011). Peer rejection and HPA activity in middle childhood: friendship makes a difference. Child Dev. 82, 1906-1920.

Petty, R. E., and Cacioppo, J. T. (1986a). Communication and Persuasion: Central and Peripheral Routes to Attitude Change. New York, NY: Springer-Verlag.

Petty, R. E., and Cacioppo, J. T. (1986b). The elaboration likelihood model of persuasion. Adv. Exp. Soc. Psychol. $19,123-205$.

Pinsonneault, J. K., Han, D. D., Burdick, K. E., Kataki, M., Bertolino, A., Malhotra, A. K., Gu, H. H., and Sadee, W. (2011). Dopamine transporter gene variant affecting expression in human brain is associated with bipolar disorder. Neuropsychopharmacology 36, 1644-1655.

Pinsonneault, J. K., Papp, A. C., and Sadee, W. (2006). Allelic mRNA expression of $\mathrm{X}$-linked monoamine oxidase a (MAOA) in human brain: dissection of epigenetic and genetic factors. Hum. Mol. Genet. 15, 2636-2649.

Plassmann, H., O'Doherty, J., and Rangel, A. (2007). Orbitofrontal cortex encodes willingness to pay in everyday economic transactions. $J$. Neurosci. 27, 9984-9988.

Plassmann, H., O’Doherty, J., Shiv, B., and Rangel, A. (2008). Marketing actions can modulate neural representations of experienced pleasantness. Proc. Natl. Acad. Sci. U.S.A. 105, 1050-1054.

Plomin, R., Owen, M. J., and McGuffin, P. (1994). The genetic basis of complex human behaviors. Science 264, 1733-1739.

Price, D. D., Vondergruen, A., Miller, J., Rafii, A., and Price, C. (1985). A psychophysical analysis of morphine analgesia. Pain 22, 261-269.

Ramchandani, V. A., Umhau, J., Pavon, F. J., Ruiz-Velasco, V., Margas, W., Sun, H., Damadzic, R., Eskay, R., Schoor, M., Thorsell, A., Schwandt, M. L., Sommer, W. H., George, D. T., Parsons, L. H., Herscovitch, P., Hommer, D., and Heilig, M. (2010). A genetic determinant of the striatal dopamine response to alcohol in men. Mol. Psychiatry 16, 809-817.

Ray, L. A., and Hutchison, K. E. (2004). A polymorphism of the mu-opioid receptor gene (OPRM1) and sensitivity to the effects of alcohol in humans. Alcohol. Clin. Exp. Res. 28, 1789-1795.

Ray, L. A., Miranda, R. Jr., Tidey, J. W., Mcgeary, J. E., Mackillop, J., Gwaltney, C. J., Rohsenow, D. J., Swift, R. M., and Monti, P. M. (2010). Polymorphisms of the mu-opioid receptor and dopamine D4 receptor genes and subjective responses to alcohol in the natural environment. J. Abnorm. Psychol. 119, 115-125.

Reyes-Gibby, C. C., Shete, S., Rakvag, T., Bhat, S. V., Skorpen, F., Bruera, E., Kaasa, S., and Klepstad, P. (2007). Exploring joint effects of genes and the clinical efficacy of morphine for cancer pain: OPRM1 and COMT gene. Pain 130, 25-30.

Sabol, S. Z., Hu, S., and Hamer, D. (1998). A functional polymorphism in the monoamine oxidase A gene promoter. Hum. Genet. 103, 273-279.

Schmahl, C., Ludascher, P., Greffrath, W., Kraus, A., Valerius, G., Schulze, T. G., Treutlein, J., Rietschel, M., Smolka, M. N., and Bohus, M. (2012). COMT val158met polymorphism and neural pain processing. Plos ONE 7:e23658. doi: 10.1371/journal.pone.0023658

Seymour, B., O’Doherty, J. P., Dayan, P., Koltzenburg, M., Jones, A. K., Dolan, R. J., Friston, K. J., and Frackowiak, R. S. (2004). Temporal difference models describe higherorder learning in humans. Nature 429, 664-667.

Sherif, M. (1936). The Psychology of Social Norms. New York, NY: Harper and Row.

Shih, J. C., Chen, K., and Ridd, M. J. (1999). Monoamine oxidase: from genes to behavior. Annu. Rev. Neurosci. 22, 197-217.

Sia, A. T., Lim, Y., Lim, E. C. P., Goh, R. W. C., Law, H. Y., Landau, R., Teo, Y. Y., and Tan, E. C. (2008). A118G single nucleotide polymorphism of human mu-opioid receptor gene influences pain perception and patient-controlled intravenous morphine consumption after intrathecal morphine for postcesarean analgesia. Anesthesiology 109, 520-526.

Skinner, B. F. (1963). Operant behavior. Am. Psychol. 18, 503-515.

Slavich, G. M., Way, B. M., Eisenberger, N. I., and Taylor, S. E. (2010) Neural sensitivity to social rejection is associated with inflammatory responses to social stress. Proc. Natl. Acad. Sci. U.S.A. 107, 14817-14822.

Sobotka, S. S., Davidson, R. J., and Senulis, J. A. (1992). Anterior brain electrical asymmetries in response to reward and punishment. Electroencephalogr. Clin. Neurophysiol. 83, 236-247.

Solanto, M. V. (1998). Neuropsychopharmacological mechanisms of stimulant drug action in attention-deficit hyperactivity disorder: a review and integration. Behav. Brain Res. 94, 127-152.

Spanagel, R., Herz, A., and Shippenberg, T. S. (1992). Opposing tonically active endogenous opioid systems modulate the mesolimbic dopaminergic pathway. Proc. Natl. Acad. Sci. U.S.A. 89, 2046-2050.

Spear, L. P. (2009). The Behavioral Neuroscience of Adolescence. New York, NY: WW Norton and Company.

Steinberg, L. (2008). A social neuroscience perspective on adolescent risk-taking. Dev. Rev. 28, 78-106.

Stormshak, E. A., Bierman, K. L. Bruschi, C., Dodge, K. A., and Coie, J. D. (1999). The relation between behavior problems and peer preference in different classroom contexts. conduct problems prevention research group. Child Dev. 70 , 169-182.

Sulik, M. J., Eisenberg, N., LemeryChalfant, K., Spinrad, T. L., Silva, K. M., Eggum, N. D., and Verrelli, B. C. (2012). Interactions between serotonin transporter gene haplotypes and quality of mothers' parenting predict the development of children's noncompliance. Dev. Psychol. $48,740-754$.

Svingos, A. L., Garzon, M., Colago, E. E., and Pickel, V. M. (2001) $\mathrm{Mu}$-opioid receptors in the ventral tegmental area are targeted to presynaptically and directly modulate mesocortical projection neurons. Synapse 41, 221-229.

Takahashi, H., Kato, M., Matsuura, M., Mobbs, D., Suhara, T., and Okubo, Y. (2009). When your gain is my pain and your pain is my gain: neural correlates of envy and schadenfreude. Science 323, 937-939.

Tan, E. C., Lim, Y., Teo, Y. Y., Goh, R., Law, H. Y., and Sia, A. T. (2008). Ethnic differences in pain perception and patient-controlled analgesia usage for postoperative pain. J. Pain 9, 849-855.

Taylor, S. E., Way, B. M., Welch, W. T. Hilmert, C. J., Lehman, B. J., and Eisenberger, N. I. (2006). Early family environment, current adversity, the serotonin transporter promoter polymorphism, and depressive symptomatology. Biol. Psychiatry 60, 671-676.

Tusche, A., Bode, S., and Haynes, J. D. (2010). Neural responses to unattended products predict later consumer choices. J. Neurosci. 30 , 8024-8031.

Vandenbergh, D. J., Persico, A. M., Hawkins, A. L., Griffin, C. A., Li, X., Jabs, E. W., and Uhl, G. R. (1992). Human dopamine transporter gene (DAT1) maps to chromosome-5p15.3 and displays a VNTR. Genomics 14, 1104-1106.

VanNess, S., Owens, M., and Kilts, C. (2005). The variable number of tandem repeats element in DAT1 regulates in vitro dopamine transporter density. BMC Genet. 6, 55.

Volkow, N. D., Wang, G. J., Fowler, J. S., Logan, J., Gerasimov, M., Maynard, L., Ding, Y. S., Gatley, S. J., Gifford, A., and Franceschi, D. (2001). Therapeutic doses of oral methylphenidate significantly increase extracellular dopamine in the human brain. J. Neurosci. 21, U1-U5.

Volkow, N. D., Wang, G. J., Fowler, J. S., Logan, J., Jayne, M., Franceschi, D., Wong, C., Gatley, S. J., Gifford, A. N., Ding, Y. S., and Pappas, N. (2002). "Nonhedonic" food motivation in humans involves dopamine in the dorsal striatum and methylphenidate amplifies this effect. Synapse 44, 175-180.

Volkow, N. D., Wang, G. J., Fowler, J. S., Telang, F., Maynard, L., Logan, J., Gatley, S. J., Pappas, N., Wong, C., Vaska, P., Zhu, W., and Swanson, J. M. (2004). Evidence that methylphenidate enhances the saliency of a mathematical task by increasing dopamine in the human brain. Am. J. Psychiatry 161, 1173-1180.

Vollenweider, F. X., Maguire, R. P., Leenders, K. L., Mathys, K., and Angst, J. (1998). Effects of high amphetamine dose on mood and cerebral glucose metabolism in normal volunteers using positron emission tomography (PET). Psychiatry Res. 83, 149-162.

Way, B., and Gurbaxani, B. M. (2008). A genetics primer for social health research. Soc. Pers. Psychol. Compass 2, 785-816.

Way, B. M., Lacan, G., Fairbanks, L. A., and Melega, W. P. (2007). Architectonic distribution of the serotonin transporter within the orbitofrontal cortex of the vervet monkey. Neuroscience 148, 937-948.

Way, B. M., and Taylor, S. E. (2010). Social influences on health: is serotonin a critical mediator? Psychosom. Med. 72, 107-112.

Way, B. M., Taylor, S. E., and Eisenberger, N. I. (2009). Variation in the mu-opioid receptor gene (OPRM1) is associated with 
dispositional and neural sensitivity to social rejection. Proc. Natl. Acad. Sci. U.S.A. 106, 15079-15084.

Wiers, R. W., Rinck, M., Dictus, M., and Van Den Wildenberg, E. (2009). Relatively strong automatic appetitive action-tendencies in male carriers of the OPRM1 G-allele. Genes Brain Behav. 8, 101-106.

Williams, K. D., Cheung, C. K., and Choi, W. (2000). Cyberostracism: effects of being ignored over the internet. J. Pers. Soc. Psychol. 79, 748-762.

Williams, K. D., and Sommer, K. L. (1997). Social ostracism by one's coworkers: Does rejection lead to loafing or compensation? Pers. Soc. Psychol. Bull. 23, 693-706.

Wong, D. T., Bymaster, F. P., and Engleman, E. A. (1995). Prozac (fluoxetine, Lilly 110140), the first selective serotonin uptake inhibitor and an antidepressant drug: twenty years since its first publication. Life Sci. 57, 411-441.

Wright, J. C., Giammarino, M., and Parad, H. W. (1986). Social status in small groups: Individualgroup similarity and the social "misfit." J. Pers. Soc. Psychol. 50, 523-536.

Yacubian, J., and Buchel, C. (2009). The genetic basis of individual differences in reward processing and the link to addictive behavior and social cognition. Neuroscience 164, 55-71.

Yacubian, J., Sommer, T., Schroeder, K., Glascher, J., Kalisch, R., Leuenberger, B., Braus, D. F., and Buchell, C. (2007). Gene-gene interaction associated with neural reward sensitivity. Proc. Natl. Acad. Sci. U.S.A. 104, 8125-8130.

Yavich, L., Forsberg, M. M., Karayiorgou, M., Gogos, J. A., and Mannisto, P. T. (2007). Site-specific role of catechol-Omethyltransferase in dopamine overflow within prefrontal cortex and dorsal striatum. J. Neurosci. 27, 10196-10202.

Zaki, J., Schirmer, J., and Mitchell, J. P. (2011). Social influence modulates the neural computation of value. Psychol. Sci. 22, 894-900.
Zhong, S., Chark, R., Ebstein, R. P., and Chew, S. H. (2012). Imaging genetics for utility of risks over gains and losses. Neuroimage 59, 540-546.

Zhong, S., Israel, S., Xue, H., Sham, P. C., Ebstein, R. P., and Chew, S. H. (2009). A neurochemical approach to valuation sensitivity over gains and losses. Proc. Biol. Sci. 276, 4181-4188.

Zink, C. F., Pagnoni, G., Chappelow, J., Martin-Skurski, M., and Berns, G. S. (2006). Human striatal activation reflects degree of stimulus saliency. Neuroimage 29, 977-983.

Zink, C. F., Pagnoni, G., Martin, M. E., Dhamala, M., and Berns, G. S. (2003). Human striatal response to salient nonrewarding stimuli. J. Neurosci. 23, 8092-8097.

Zink, C. F., Pagnoni, G., MartinSkurski, M. E., Chappelow, J. C., and Berns, G. S. (2004). Human striatal responses to monetary reward depend on saliency. Neuron 42, 509-517.

Zubieta, J. K., Dannals, R. F., and Frost, J. J. (1999). Gender and age influences on human brain mu-opioid receptor binding measured by PET. Am. J. Psychiatry 156, 842-848.

Conflict of Interest Statement: The authors declare that the research was conducted in the absence of any commercial or financial relationships that could be construed as a potential conflict of interest.

Received: 15 March 2012; accepted: 23 May 2012; published online: 12 June 2012.

Citation: Falk EB, Way BM and Jasinska AJ (2012) An imaging genetics approach to understanding social influence. Front. Hum. Neurosci. 6:168. doi: 10.3389/ fnhum.2012.00168

Copyright (C) 2012 Falk, Way and Jasinska. This is an open-access article distributed under the terms of the Creative Commons Attribution Non Commercial License, which permits noncommercial use, distribution, and reproduction in other forums, provided the original authors and source are credited. 